\title{
Simple and Novel Assay of the Host-Guest Complexation of Homocysteine with Cucurbit[7]uril
}

\author{
Se-Ho Park ${ }^{1,2 \dagger}$, Jae-Yeul Lee ${ }^{1,2 \dagger}$, Hyun-Nam Cho ${ }^{1}$, Kyoung-Ran Kim ${ }^{1}$, Seun-Ah Yang ${ }^{3}$, Hee-Joon Kim ${ }^{1}$, and \\ Kwang-Hwan Jhee ${ }^{1 *}$ \\ ${ }^{1}$ Department of Applied Chemistry, Kumoh National Institute of Technology, Gumi 39177, Republic of Korea \\ ${ }^{2}$ Institute of Natural Science, Keimyung University, Daegu 42601, Republic of Korea \\ ${ }^{3}$ Department of Food Science and Technology, Keimyung University, Daegu 42601, Republic of Korea
}

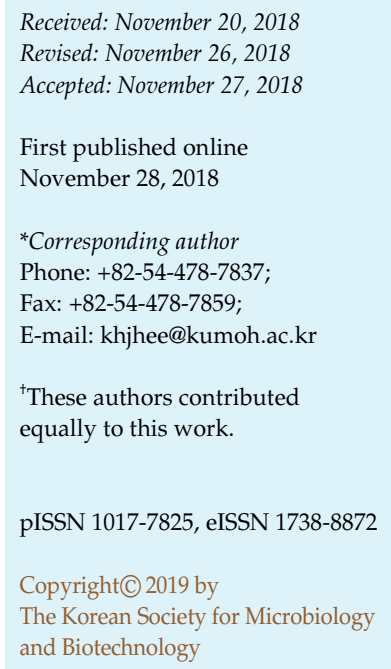

This paper introduces three ways to determine host-guest complexation of cucurbit[7]uril (CB[7]) with homocysteine (Hcy). After preincubating Hcy and cysteine (Cys) with CB[7], Ellman's reagent (DTNB) was used to detect Hcy and Cys. Only Cys reacted with DTNB and Hcy gave a retarded color change. This suggests that the - $\mathrm{SH}$ group of Hcy is buried inside CB[7]. Human cystathionine $\gamma$-lyase (hCGL) decreased the level of Hcy degradation after preincubating Hcy and $\mathrm{CB}$ [7]. These results suggest that the amount of free Hcy available was decreased by the formation of a Hcy-CB[7] complex. The immunological signal of anti-Hcy monoclonal antibody was decreased significantly by preincubating CB[7] with Hcy. The ELISA results also show that ethanethiol group $\left(-\mathrm{CH}_{2} \mathrm{CH}_{2} \mathrm{SH}\right)$ of Hcy, which is an epitope of anti-Hcy monoclonal antibody, was blocked by the cavity in $\mathrm{CB}$ [7]. Overall, CB[7] can act as a host by binding selectively with Hcy, but not Cys. The calculated half-complexation formation concentration of CB[7] was $58.2 \mathrm{nmol}$ using Ellman's protocol, $97.9 \mathrm{nmol}$ using hCGL assay and $87.7 \mathrm{nmol}$ using monoclonal antibody. The differing binding abilities of Hcy and Cys towards the $\mathrm{CB}$ [7] host may offer a simple and useful method for determining the Hcy concentration in plasma or serum.

Keywords: Homocysteine, cucurbit[7]uril, DTNB, ELISA, human cystathionine $\gamma$-lyase

\section{Introduction}

The total homocysteine (Hcy) level in plasma or serum is a sensitive indicator of vitamin B12 and folate deficiencies. This is related to complications of pregnancy, neural tube defects, mental disorders, and cognitive impairment in the elderly [1]. Furthermore, data from approximately 80 clinical and epidemiological studies provide ample evidence that an elevated Hcy level is a common cardiovascular risk factor in the general population [2-4]. Hcy is an intermediate that converts L-methionine into L-cysteine (LCys) in the sulfur metastasis pathway. Human cystathionine $\gamma$-lyase (hCGL) and human cystathionine $\beta$-synthase (hCBS) play important roles in Hcy metabolism, called the transsulfuration process [5-8]. hCGL is an enzyme that breaks down Hcy to $\alpha$-ketobutyrate, ammonia, and hydrogen sulfide $\left(\mathrm{H}_{2} \mathrm{~S}\right)$ [9]. hCGL also catalyzes L-cysteine into pyruvate, ammonia, and $\mathrm{H}_{2} \mathrm{~S}$. Several studies have reported that Hcy over-generation in rat blood causes hypertension with hCGL absence, suggesting that $\mathrm{H}_{2} \mathrm{~S}$ generation plays an important role in blood pressure regulation [10, 11]. The detection of Hcy in serum is difficult due to the similar chemical structure of Hcy and Cys. Therefore, it is important for the early diagnosis and treatment of vascular disease. Early Hcy-selective detection methods involved high-performance liquid chromatography (HPLC), electrochemical detection, capillary electrophoresis (CE), UV-Vis spectroscopy, and fluorescence spectroscopy [12-18]. Hcy detection using fluorescence spectroscopy is generally used because of its high sensitivity, facile operation, visual signal transduction, and suitability for in vivo analysis. On the other hand, the technique does not 


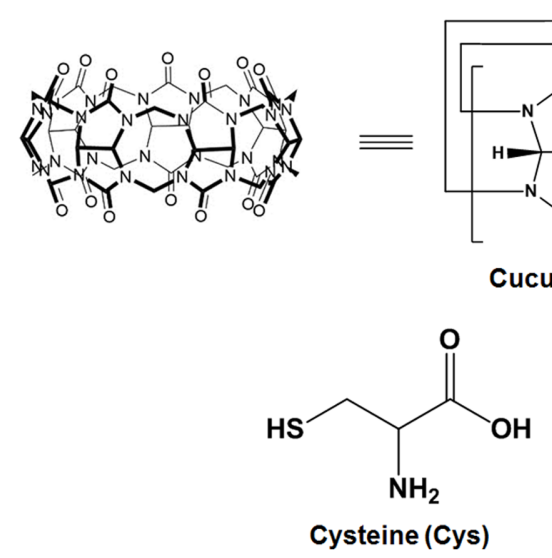

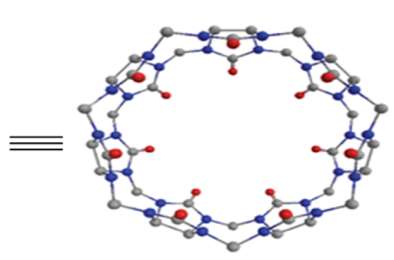

Cucurbit[7]uril<smiles>NC(CCS)C(=O)O</smiles>

Fig. 1. Chemical structures of CB[7], Cys, and Hcy.

identify Hcy and Cys due to their being in a similar reactive functional group. In addition, these techniques are expensive and have lengthy detection times. Therefore, it is important to develop specific and effective Hcy detection assays, rather than Cys detection, in aqueous solutions.

Fig. 1 presents the chemical structures of $\mathrm{CB}$ [7], Cys, and Hcy. Cys is a semi-essential proteinogenic amino acid with the formula, $\mathrm{HO}_{2} \mathrm{CCH}\left(\mathrm{NH}_{2}\right) \mathrm{CH}_{2} \mathrm{SH}$. On the other hand, Hcy is a homologue of the amino acid, Cys, differing by an additional methylene bridge $\left(-\mathrm{CH}_{2}-\right)$.

The molecular recognition and sensing properties of supramolecules have wide-ranging applications in the areas of sensing, biochip, drug delivery, and early diagnosis $[19,20]$. Cucurbit[n] uril $(C B[n])$, where $n$ indicates the number of glycoluril units $(n=5-8,10)$, are interesting supramolecules because of their specific binding with small biomolecules, peptides, and proteins depending on cavity size [21-26]. All $C B[n]$ structures have the same cavity depth, but they differ in their cavity sizes. $\mathrm{CB}$ [5] and $\mathrm{CB}[6]$ can bind with small molecules, such as gas molecules and aliphatic chains, whereas the $\mathrm{CB}[7]$ and $\mathrm{CB}[8]$ cavitycontaining substituents might accommodate other host molecules. Therefore, this study investigated the hostguest complexation of Hcy by CB[7] using a DTNB reaction, an enzymatic reaction for hCGL protein, and the ELISA assay using the anti-Hcy monoclonal antibody.

\section{Materials and Methods}

\section{Reagents}

5,5'-Dithio-Bis(2-nitrobenzoic acid (DTNB), CB[7], Cys, Hcy, polyacrylamide (37.5:1), tetramethyl ethylenediamine (TEMED), sodium dodecyl sulfate (SDS), Tris- $\mathrm{HCl}$ ( $\mathrm{pH} 8.8$ ), hydrogen peroxide $\left(\mathrm{H}_{2} \mathrm{O}_{2}\right)$, 2,2'-azino-bis(3-ethylbenzothiazoline-6-sulphonic
acid)(ABTS), calcium chloride $\left(\mathrm{CaCl}_{2}\right)$, lead acetate, bovine serum albumin (BSA), ammonium persulfate, glycerol, sodium chloride $(\mathrm{NaCl})$, imidazole, tris-(2-carboxyethyl)phosphine (TCEP), pyridoxal phosphate (PLP), terrific Broth (TB) medium, iodoacetamide, sodium borohydride $\left(\mathrm{NaBH}_{4}\right)$, skim milk, potassium buffer saline (PBS), Tris-buffer saline (TBS), protein ladder, sodium hydrogen sulfate $\left(\mathrm{NaHSO}_{4}\right)$, isopropyl $\beta$-D-1-thiogalactopyranoside (IPTG), sodium acetate, acetic acid, glutaraldehyde, and $\beta$-mercaptoethanol were purchased from Sigma-Aldrich Chemicals (USA). Secondary anti-rat IgG antibody was purchased from Cell Signaling Technology, Inc. (USA). Double-distilled water was used for all experiments.

\section{Chemical Hcy Detection Using DTNB Assay}

Hcy-CB[7] binding ratio was calculated using a DTNB colorimetric assay. DTNB, which is known as Ellman's reagent, is reacted with sulfhydryl groups (-SH), providing a reliable method to measure the amount of Hcy, Cys, and other sulfhydryl groups in a solution. Briefly, stock solutions of $5 \mathrm{mM} \mathrm{Cys,} 5 \mathrm{mM} \mathrm{Hcy}$, and $24 \mathrm{mM} \mathrm{CB}[7]$ were prepared in $100 \mathrm{mM}$ PBS, respectively. $10 \mu \mathrm{l}$ of each $200 \mu \mathrm{M}$ Cys and Hcy ( $2 \mathrm{nmol}$; final molar mass) were reacted with various molar masses of CB[7] $(48,96,144,192,240,480 \mathrm{nmol})$ for $5 \mathrm{~min}$. And then, the samples or iodoacetamide $(50 \mathrm{nmol})$ were mixed to $120 \mu \mathrm{l}$ of DTNB solution, and absorbance was measured by spectrophotometer (Agilent 8453) at $412 \mathrm{~nm}$ after 3 min reaction. Cys and Hcy were quantified using standard Cys, Hcy calibration curves. Iodoacetamide (50 nmol), which is a thiol-blocking electrophiles was used as a negative control [27].

\section{Enzymatic Assay for Hcy}

hCGL preparation. We used E. coli BL21 (DE3) as host cells by using a cloning process. The hCGL gene (pNIC-28-BsaI, encoded T7 promoter, lac operator, kanamycin resistance genes) was a gift from the Dr. Sivaraman Research Group [28]. Transformation was conducted with $\mathrm{CaCl}_{2}$-treated competent cells, and the transformants were inoculated in potassium phosphate-buffered TB medium ( $\mathrm{pH} 7.0)$ including kanamycin $(50 \mu \mathrm{g} / \mathrm{ml}$; final concentration). The 
transformed bacteria were grown, reaching approximately 2.0 of optical density at $660 \mathrm{~nm}$, and then stimulated hCGL overexpression with $0.5 \mathrm{mM}$ IPTG treatment. After incubation, bacterial suspension was centrifuged $(8,000 \mathrm{rpm}, 20 \mathrm{~min})$. Bacterial cells were treated with lysis buffer $(0.5 \mathrm{M} \mathrm{NaCl}, 20 \mathrm{mM}$ Tris-HCl, $10 \mathrm{mM}$ imidazole, $0.5 \mathrm{mM}$ TCEP, EDTA free protease inhibitor, $20 \mu \mathrm{M}$ PLP, $\mathrm{pH} 7.9$ ), and bacterial lysate was destroyed through ultrasonication for $30 \mathrm{~min}$. After ultrasonication, crude extract was obtained by centrifuging (8,000 rpm, $20 \mathrm{~min})$. hCGL protein identification was measured by using SDS-PAGE, western blot analysis, and UV-Vis spectrum [9].

Hcy, Cucurbit[7]uril binding ratio measurement using hCGL. The Hcy-CB[7] binding ratio was determined by $\mathrm{H}_{2} \mathrm{~S}$, which is a product of $\alpha, \gamma$-elimination reaction of hCGL [9]. Briefly, $5 \mathrm{mM}$ Cys, $5 \mathrm{mM} \mathrm{Hcy}$, and $24 \mathrm{mM} \mathrm{CB[7]} \mathrm{were} \mathrm{dissolved} \mathrm{with} 100 \mathrm{mM}$ PBS. $200 \mu \mathrm{M}$ Cys and Hcy (10 $\mu \mathrm{l}$, final molar mass: $2 \mathrm{nmol})$ were reacted with various molar masses of $\mathrm{CB}[7](48,96,144,192,240$, $480 \mathrm{nmol}$ ) for $5 \mathrm{~min}$. Next, the samples were mixed to $120 \mu \mathrm{l}$ of hCGL solution (hCGL $30 \mu \mathrm{g}, 50 \mathrm{mM}$ KPB buffer, pH 8.0, $0.4 \mathrm{mM}$ $\mathrm{Pb}$-acetate, $20 \mu \mathrm{M}$ PLP) for $5 \mathrm{~min}$ and absorbance was measured by spectrophotometer at $360 \mathrm{~nm}$. Cys and Hcy were quantified using standard Cys, Hcy calibration curves.

\section{Optimization of Anti-Hcy Monoclonal Antibody}

Indirect ELISA analysis of anti-Hcy monoclonal antibody specificity. Anti-Hcy monoclonal antibody was prepared by modified assay using hybridoma cells [29]. Briefly, 5\% glutaraldehyde (in $3 \mathrm{M}$ acetate buffer, $\mathrm{pH}$ 7.8) was reacted with an amino group $\left(-\mathrm{NH}_{2}\right)$ coated 96-well plate at room temperature for $2 \mathrm{~h}$, and then, each well was washed with PBS twice. $1.5 \mathrm{M} \mathrm{NaBH}_{4}$ (in $3 \mathrm{M}$ acetate buffer) was treated in each well for $2 \mathrm{~h}$, and the 96well plate was washed twice using PBS. After $\mathrm{NaBH}_{4}$ treatment, 22 amino acids containing seleno-Cys (SeCys), D,L-Hcy in $3 \mathrm{M}$ acetate buffer were reacted with the 96-well plate for $1 \mathrm{~h}$. After this 1 h-reaction, each well was blocked by $5 \%$ skim milk $400 \mu$, and then the plate was washed twice using PBS. The 22 amino acid-coated wells were then reacted with anti-Hcy monoclonal antibody for $1 \mathrm{~h}$. After each well was washed twice with TBS solution, the wells were then reacted with secondary antibody (1:10,000 dilution) for $1 \mathrm{~h}$. Each well was again washed twice with TBS solution, and $100 \mu \mathrm{l}$ of reaction solution (ABTS $5 \mathrm{mg}, 30 \%$ $\mathrm{H}_{2} \mathrm{O}_{2}$ in $0.1 \mathrm{M}$ Sodium citrate, $\mathrm{pH}$ 4.6) was added to each well at room temperature.

DTNB assay for binding specificity between Hcy and antiHcy monoclonal antibody. To investigate the specificity for antiHcy monoclonal antibody, we performed the DTNB assay. Briefly, Cys and Hcy were reacted with anti-Hcy monoclonal antibody for $2 \mathrm{~h}$ at room temperature. The mixtures of 'Cys + anti-Hcy monoclonal antibody $(10 \mu \mathrm{l})$ ' and 'Hcy + anti-Hcy monoclonal antibody $(10 \mu \mathrm{l})^{\prime}$ were added to the DTNB mixture (DTNB solution $50 \mu \mathrm{l}$, Tris- $\mathrm{HCl}$ ( $\mathrm{pH} 8.0) 100 \mu \mathrm{l}$, and distilled water $840 \mu \mathrm{l}$ ). The absorbance was measured by spectrophotometer at $412 \mathrm{~nm}$. Cys and Hcy were quantified using standard Cys and Hcy calibration curves. Iodoacetamide $(50 \mathrm{nmol})$ was used as a negative control.

Immunofluorescence assay of Hcy detection. We performed a competitive ELISA for anti-Hcy monoclonal antibody sensitivity. Briefly, a Hcy-coated ELISA plate was prepared and blocked with $5 \%$ skim milk. Various concentrations of Hcy $(0.001,0.01,0.1,1$, $10 \mathrm{mM}$ ) were preincubated with anti-Hcy monoclonal antibody for $2 \mathrm{~h}$ at room temperature. Hcy and anti-Hcy monoclonal antibody mixture was added to each well $(50 \mu \mathrm{l})$ for $1 \mathrm{~h}$ at room temperature, and then each well was washed with TBS solution. Then, each well was reacted with secondary antibody (1:10,000 dilution) $100 \mu \mathrm{l}$ for $1 \mathrm{~h}$ followed by washing with TBS solution. After the reaction solution (ABTS $5 \mathrm{mg}$ and $30 \% \mathrm{H}_{2} \mathrm{O}_{2} 0.35 \mu \mathrm{l}$ in $10 \mathrm{ml}$ sodium citrate) was added to each well, the absorbance was measured by ELISA reader at $405 \mathrm{~nm}$.

Sensitivity check for anti-Hcy monoclonal antibody using iodoacetamide, inhibitor of -SH. To evaluate anti-Hcy monoclonal antibody sensitivity, we used a thiol blocking reagent, iodoacetamide. Briefly, a Hcy-coated ELISA plate was blocked with 5\% skim milk in PBS solution. To check the antigen blocking ability, each well was treated with various concentrations of iodoacetamide $(1,10,20,30,40,50,60,70,80,90$, and $100 \mathrm{nM})$ in ammonium bicarbonate for $1 \mathrm{~h}$ at room temperature followed by two washings with PBS. Next, anti-Hcy monoclonal antibody $(50 \mu \mathrm{l})$ was added to each well for $1 \mathrm{~h}$ at room temperature followed by washing with TBS. Each well was then treated with secondary antibody (rat, 1:10,000 dilution) for $1 \mathrm{~h}$, and then each well was washed with TBS solution. The reaction reagent $100 \mu \mathrm{l}$ (ABTS $5 \mathrm{mg}, 30 \% \mathrm{H}_{2} \mathrm{O}_{2} 0.35 \mu \mathrm{l}$ in sodium citrate) was then used to treat the wells for $5 \mathrm{~min}$ at room temperature. The absorbance at $405 \mathrm{~nm}$ was measured by ELISA reader.

Detection and visualization of Hcy in cells using anti-Hcy monoclonal antibody. To check the specificity for anti-Hcy monoclonal antibody, we used calf pulmonary artery endothelial cells (CPAE cells, KCTC, Korea). CPAE cells were cultured in RPMI 1640 medium supplemented with 10\% fetal bovine serum (FBS) and $1 \%$ gentamycin. For all experiments, CPAE cells were maintained until $80 \%$ confluence at $37^{\circ} \mathrm{C}, 5 \% \mathrm{CO}_{2}$ condition. Briefly, CPAE cells were covered with a cover glass, and then washed twice with PBS solution. After washing, $5 \%$ glutaraldehyde in $3 \mathrm{M}$ sodium acetate was treated with CPAE cells, and $1 \mathrm{M}$ $\mathrm{NaBH}_{4}$ was treated for $1 \mathrm{~h}$. The CPAE cells were washed with PBS solution, and treated with $0.5 \%$ BSA for $1 \mathrm{~h}$. Anti-Hcy monoclonal antibody (1:100 dilution) was reacted to CPAE cells for $1 \mathrm{~h}$. The CPAE cells were then washed twice with PBS solution and treated with secondary antibody (1:1,000 dilution) under dark conditions for $1 \mathrm{~h}$ followed by two washings with PBS. The CPAE cells were next treated with $30 \%$ glycerol directly for $3 \mathrm{~min}$, and observed using fluorescence microscopy (Eclipse E600, Nikon, Japan).

\section{Hcy-CB[7] Complexation Assay Using Indirect ELISA}

Hcy-coated enzyme-linked immunosorbent assay preparation. Briefly, $5 \%$ glutaraldehyde (in $3 \mathrm{M}$ acetate buffer, $\mathrm{pH}$ 7.8) was 
reacted with an amino group $\left(-\mathrm{NH}_{2}\right)$ coated 96-well plate at room temperature for $2 \mathrm{~h}$ followed by two washings with PBS. Each well was treated with $1.5 \mathrm{M} \mathrm{NaBH}_{4}$ (in $3 \mathrm{M}$ acetate buffer) for $2 \mathrm{~h}$, and the 96-well plate was washed twice using PBS. $50 \mu \mathrm{l}$ of $4 \mu \mathrm{M}$ Hcy in $3 \mathrm{M}$ acetate buffer ( $2 \mathrm{nmol}$; final molar mass of Hcy in a 96well ELISA plate surface) were reacted to the 96-well plate for $1 \mathrm{~h}$. Each well was treated with $50 \mu \mathrm{l}$ of $2 \mathrm{M} \mathrm{NaBH}_{4}$ for $30 \mathrm{~min}$, and then the plate was washed twice using PBS.

Hcy-CB[7] coupling reaction using indirect ELISA. The Hcycoated 96-well ELISA plate was blocked with 5\% skim milk and washed twice with PBS. Each well was treated with various molar masses of CB[7] $(48,96,144,192,240,480 \mathrm{nmol})$ for $1 \mathrm{~h}$ followed by two washings with PBS. Next, each well was treated with antiHcy monoclonal antibody $(50 \mu \mathrm{l})$ at room temperature for $1 \mathrm{~h}$ followed by two washings in Tris-buffed saline (TBS, pH 7.0). Then, secondary anti-rat antibody (1:1,000 dilution) was reacted with each well at room temperature for $1 \mathrm{~h}$ followed by two washings with TBS. Each well was then treated with the reaction solution $\left(30 \% \mathrm{H}_{2} \mathrm{O}_{2} 1.75 \mu \mathrm{l}\right.$, ABTS $25 \mathrm{mg}$ in TBS) $100 \mu \mathrm{l}$ and absorbance was measured by spectrophotometer at $405 \mathrm{~nm}$ after $10 \mathrm{~min}$ incubation. Iodoacetamide $(50 \mathrm{nmol})$ was used as a negative control.

\section{Hcy-CB[7] Complexation Determination}

The apparent $\mathrm{C}_{50 \%}$ values for chemical, enzymatic, and immunological assays for Hcy-CB[7] complexation were calculated from the equation of $\Delta \mathrm{A}=\Delta \mathrm{A}_{\max }\{\mathrm{CB}[7]\} / \mathrm{C}_{50 \%}+\{\mathrm{CB}[7]\}$. The species with maximum absorbances at 412,360 , and $405 \mathrm{~nm}$, are attributed to the Hcy-CB[7] complex, respectively. The data derived from the above experiments were used to estimate the $\mathrm{C}_{50 \%}$ values using SigmaPlot software (Version 14.0, Sigma, USA).

\section{Statistical Analysis}

Data were expressed as the mean \pm SD determined from triplicate analysis. Results were analyzed using Student's t-test and $p<0.05$ was considered significantly different.

\section{Results}

\section{Chemical Detection of Hcy by CB[7]}

The chemical detection efficacy of Hcy-CB[7] complexes were examined using a DTNB assay [30]. The DTNB assay is known to be a reversible reaction and is available for host-guest binding studies [31]. Treating the DTNB reagent with Cys $(5,7.5,10,12.5$, and $15 \mathrm{nmol})$ or Hcy $(5,7.5,10$, 12.5 , and $15 \mathrm{nmol}$ ) increased absorbance at $412 \mathrm{~nm}$ as a result of the thiol groups of Cys and Hcy (Figs. 2A and 2B). In this study, 2 nmol for Cys and Hcy was selected. Cys alone and after incubation Cys with CB[7] (2:240 ratio) did not alter the absorbance at $412 \mathrm{~nm} \mathrm{(0.104} \mathrm{and} \mathrm{0.108,}$ respectively), suggesting that $\mathrm{Cys}$ did not combine with $\mathrm{CB}$ [7] (Fig. 2C). On the other hand, Hcy alone and incubation Hcy with CB[7] (2:48, 2:96, 2:144, 2:192, 2:240, and 2:480 ratio) decreased the absorbance at $412 \mathrm{~nm}$ (Fig. 2D). These results suggest that Hcy could combine with $\mathrm{CB}[7]$; hence, the thiol groups (-SH) of Hcy blocked the $\mathrm{CB}$ [7] cavity. The absorbance of the iodoacetamidetreated Cys and Hcy at $412 \mathrm{~nm}$ decreased to 0.00172 and 0.00809, respectively, compared to those of Cys and Hcy alone because iodoacetamide reacts with - $\mathrm{SH}$ groups (Figs. 2C and 2D). These results suggest that the $\mathrm{CB}$ [7] concentration of half complex formation $\left(C_{50 \%}\right.$ value) for $2 \mathrm{nmol}$ of Hcy is $58.2 \mathrm{nmol}$. (Fig. 2E). The DTNB assay confirmed that $\mathrm{CB}[7]$ could bind selectively to Hcy. On the other hand, Cys did not bind with $\mathrm{CB}[7]$; the unreacted DTNB reagents were changed to Cys-TNB and TNBmolecules (Fig. 2F).

\section{Enzymatic Detection of Hcy by CB[7]}

The enzymatic detection assay using a hCGL protein reaction between Hcy and $\mathrm{CB}$ [7] complexes was attempted. As shown in Fig. 3A, hCGL is an enzyme that breaks down Cys ( $\alpha, \beta$-elimination reaction) and Hcy $(\alpha, \gamma$-elimination reaction) to $\mathrm{H}_{2} \mathrm{~S}, \alpha$-ketobutyrate, pyruvate, and ammonia. The gaseous product, $\mathrm{H}_{2} \mathrm{~S}$, reacts with lead acetate to form lead sulfide (PbS), which can be monitored by a spectrophotometer by the increase in absorbance at $360 \mathrm{~nm}$ (Fig. 3A) [32]. When various quantities of Hcy $(2,4,6,8$, and $10 \mathrm{nmol})$ and Cys $(2,4,6,8$, and $10 \mathrm{nmol})$ were used, the level of $\mathrm{PbS}$ production by the hCGL reaction was $0.1467,0.1968,0.2522,0.3429$, and 0.4165 , respectively, for Hcy, and $0.1361,0.1851,0.2552,0.3314$, and 0.4056 , respectively, for Cys (Figs. 3B and 3C). The appropriate Cys and Hcy quantities selected for the next experiments were $2 \mathrm{nmol}$ each. When Hcy was preincubated with $\mathrm{CB}$ [7] before the hCGL reaction at various Hcy:CB[7] ratios (2:48, 2:96, 2:144, $2: 192,2: 240$, and 2:480) the absorbance at $360 \mathrm{~nm}$ decreased (0.1034, 0.0894, 0.0830, 0.0765, 0.0730, and 0.0675, respectively), but Cys-CB[7] changed within an insignificant range (Fig. 3D). The data suggest that $\mathrm{CB}$ [7] bound specifically to Hcy, not Cys, which is consistent with the DTNB experimental data. From the enzymatic reaction assay data, the $\mathrm{C}_{50 \%}$ value of $\mathrm{CB}$ [7] was calculated to be 97.7 nmol (Fig. 3E). Hcy combined effectively with CB[7]; the hCGL enzyme could not perform an $\alpha, \gamma$-elimination reaction against Hcy (Fig. 3F).

\section{Specific Reaction between Hcy and Anti-Hcy Monoclonal Antibody}

This study next examined whether the anti-Hcy monoclonal antibody could bind to D,L-Hcy, but not 21 amino acids 

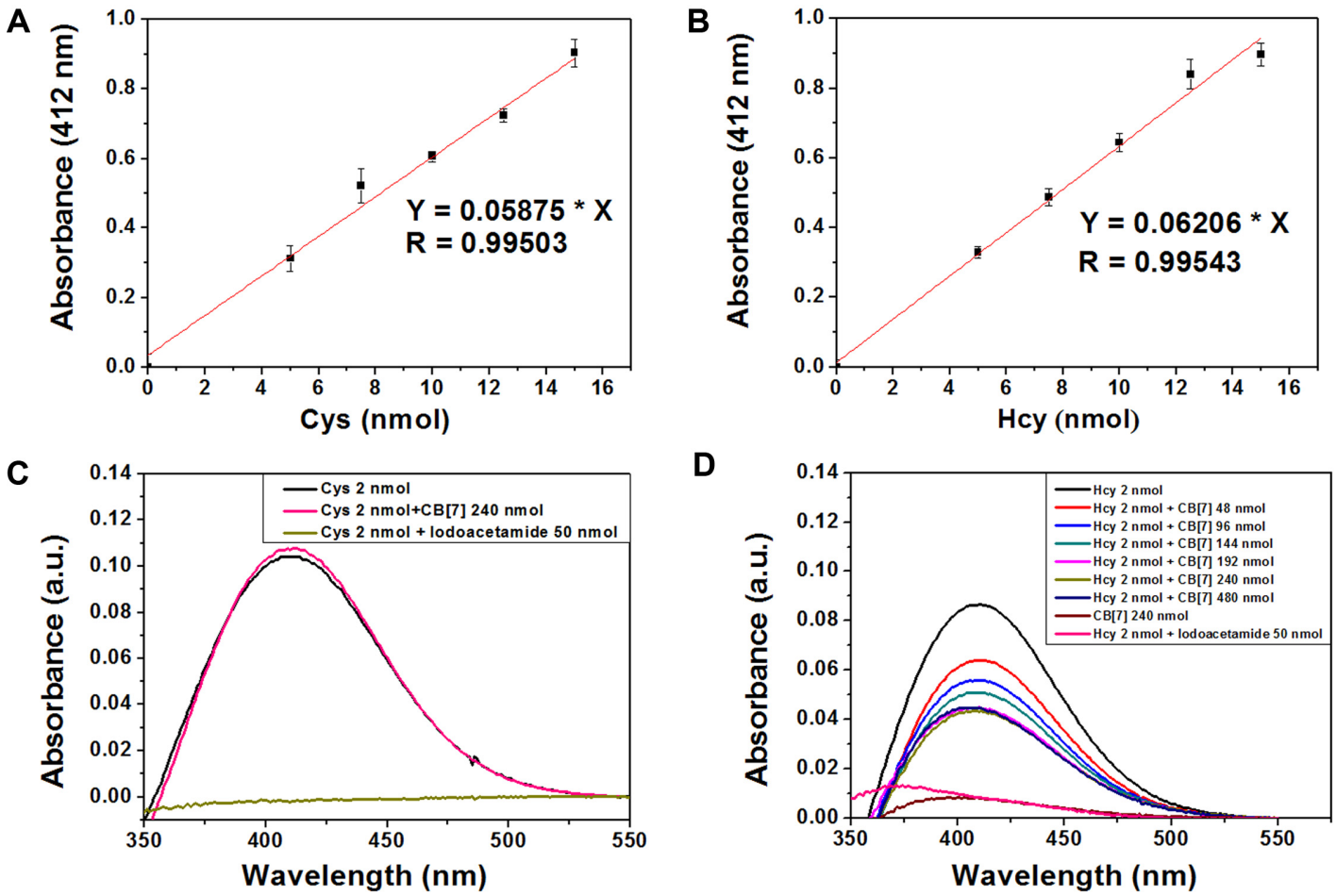

D
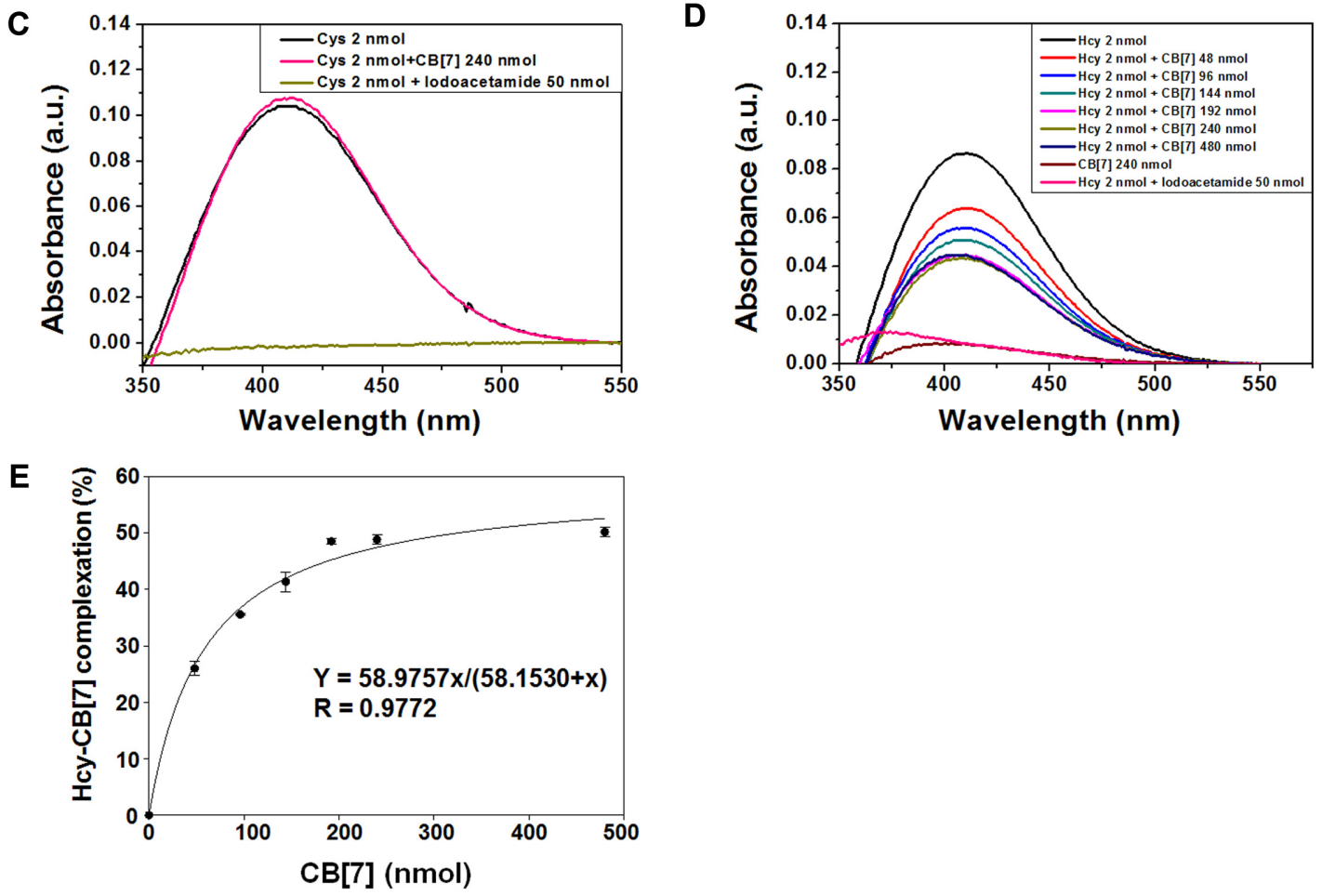

$\mathbf{F}$
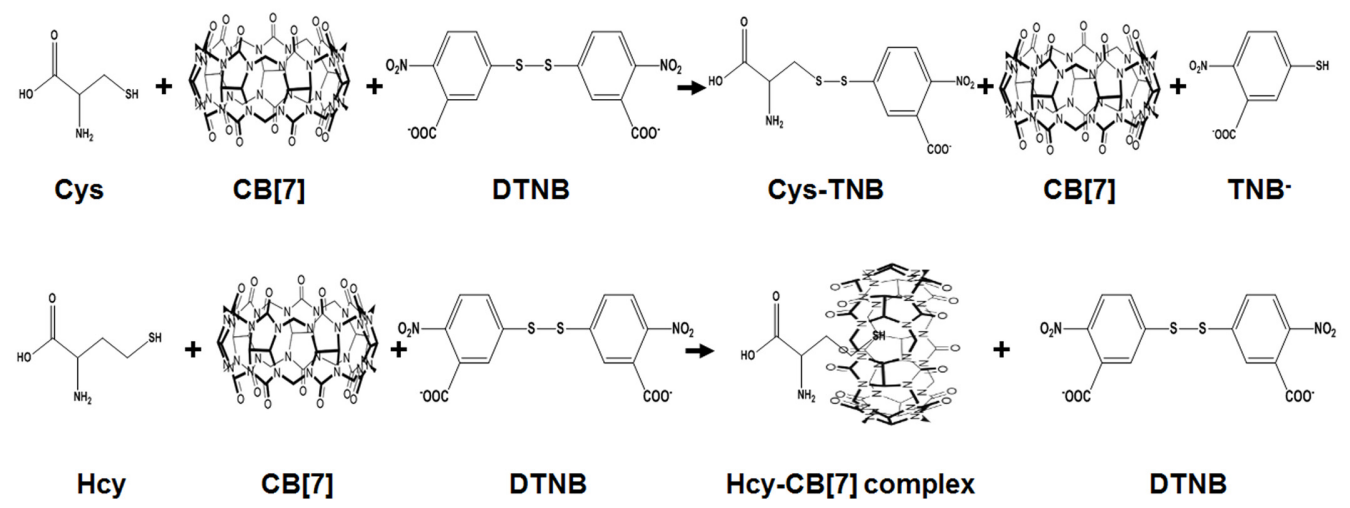

Fig. 2. Calibration curves of (A) Cys; (B) Hcy using the DTNB reagent.

Absorbance changes after preincubation with CB[7] and (C) Cys; (D) Hcy in advance before the DTNB assay; (E) Calculated half complexation formation concentration $\left(\mathrm{C}_{50 \%}\right.$ value) for $\mathrm{CB}[7]$ from absorbance change by the equation, $\Delta \mathrm{A}=\Delta \mathrm{A}_{\max }\{\mathrm{CB}[7]\} / \mathrm{C}_{50 \%}+\{\mathrm{CB}[7]\} ;(\mathrm{F}) \mathrm{Schematic}$ image of Hcy detection process using $\mathrm{CB}[7]$. 

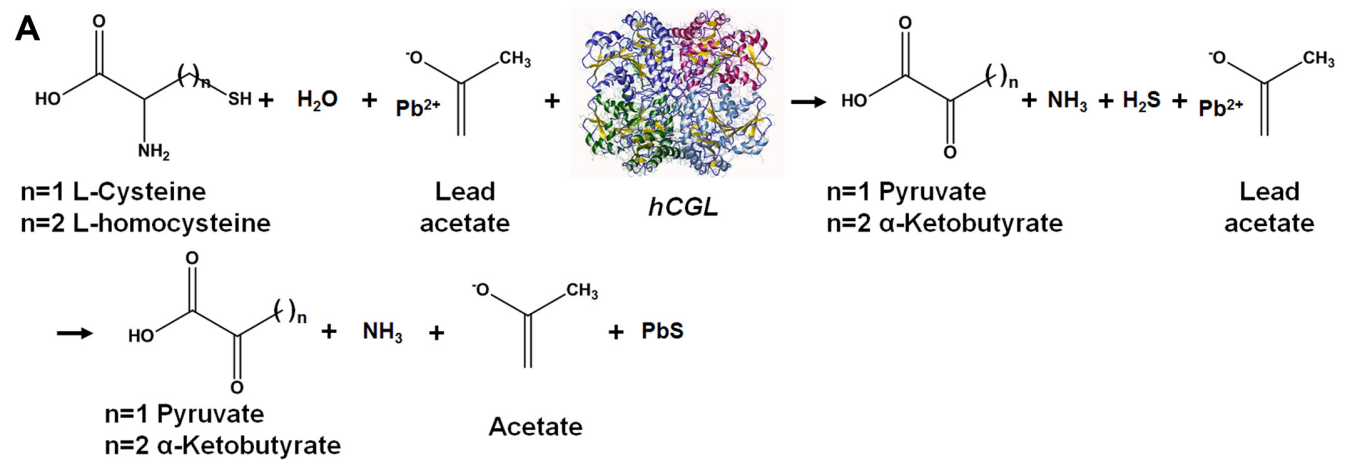

B

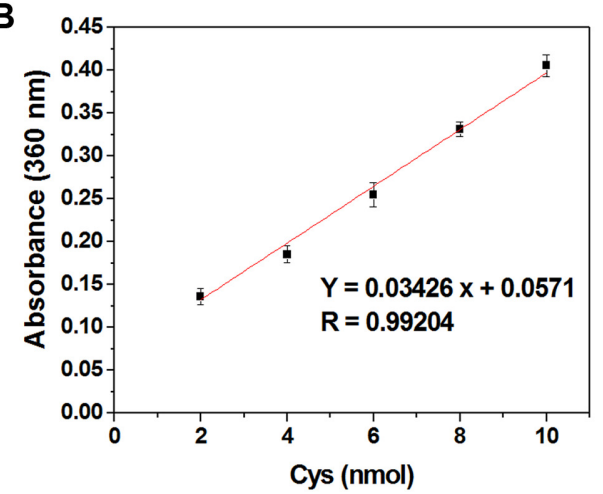

D

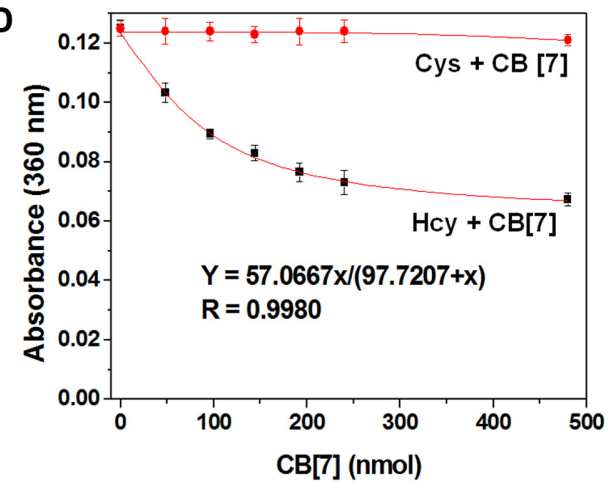

C

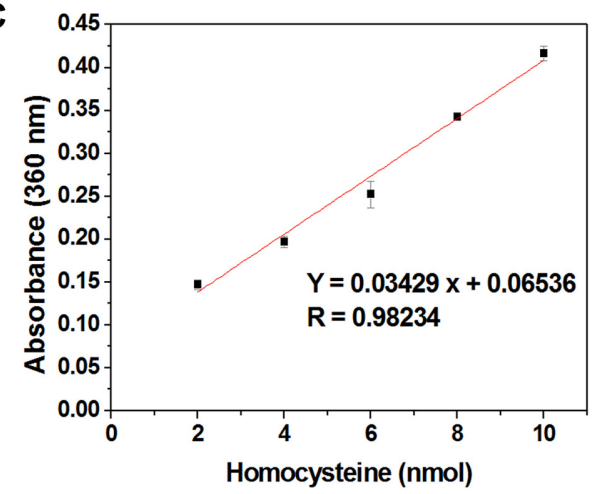

E

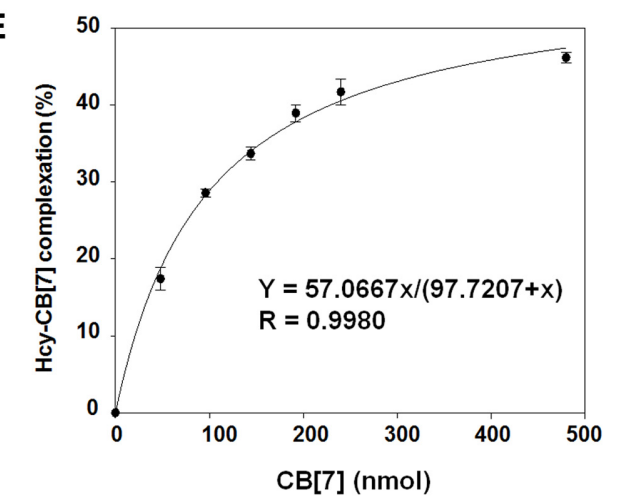

$\mathbf{F}$

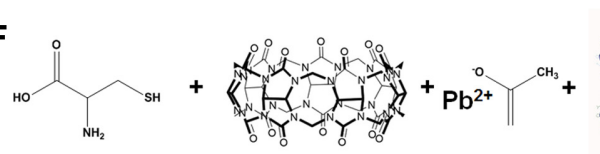

Cys

$\mathrm{CB}[7]$

Lead acetate
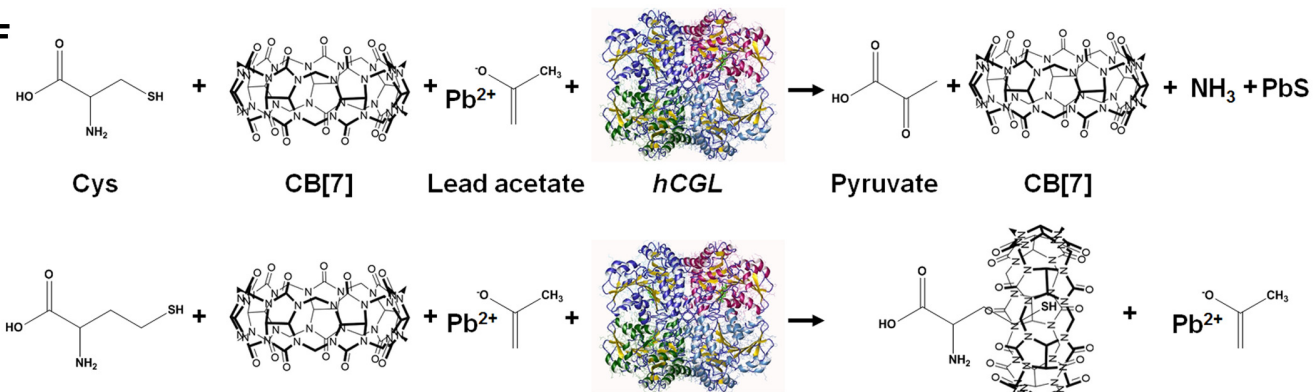

Hcy

$\mathrm{CB}[7] \quad$ Lead acetate

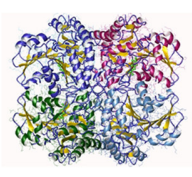

$h C G L$

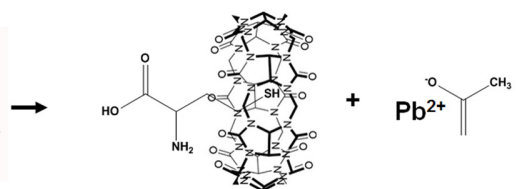

Hcy-CB[7] complex Lead acetate

Fig. 3. Enzymatic detection method for Hcy.

Absorption changes when $\mathrm{CB}[7]$ and Hcy (or Cys) was preincubated before the hCGL reaction; (A) hCGL catalyzes Cys and Hcy into $\alpha$-keto acid and $\mathrm{H}_{2} \mathrm{~S}$, which can be detected by the absorbance change with lead acetate at $360 \mathrm{~nm}$ to form a precipitate; $\mathrm{H}_{2} \mathrm{~S}$ calibration curves of (B) Cys; (C) Hcy. (D) Hcy-CB[7] complexation using the hCGL enzyme; (E) Calculated $\mathrm{C}_{50 \%}$ value for $\mathrm{CB}[7]$ from absorbance change by the equation, $\triangle \mathrm{A}=$ $\Delta \mathrm{A}_{\max }\{\mathrm{CB}[7]\} / \mathrm{C}_{50 \%}+\{\mathrm{CB}[7]\} ;(\mathrm{F})$ Schematic image of the enzymatic detection method for Hcy by Hcy-CB[7] complexation formation. 
A

\begin{tabular}{|c|c|c|c|}
\hline \multicolumn{3}{|c|}{ Amino acids } & \\
\hline Gly & Phy & Asn & \\
\hline Ala & Trp & Gln & \\
\hline Val & Tyr & Asp & \\
\hline Leu & Ser & Glu & \\
\hline Ile & Thr & D-Hcy & \\
\hline Cys & His & L-Hcy & \\
\hline Met & Lys & SeCys & \\
\hline Pro & Arg & G.A. & \\
\hline
\end{tabular}

B

1

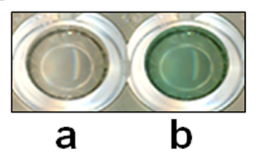

2

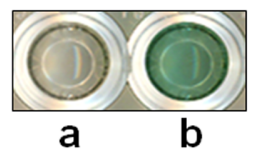

3

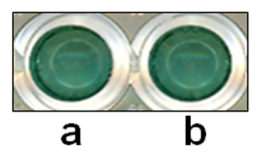

C

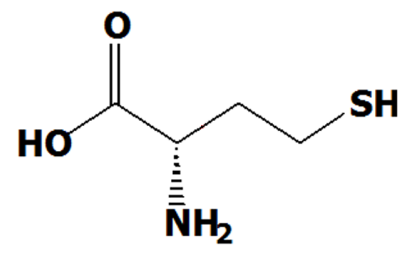

Hcy

Fig. 4. Optimization of the anti-Hcy monoclonal antibody.

(A) Indirect ELISA for 23 amino acids and glutaraldehyde (G.A.)-coated ELISA plate surface (SeCys: seleno-Cys, G.A.: glutaraldehyde); (B) binding site (epitope) identification of the anti-Hcy monoclonal antibody, 1(a): D,L-Hcy coating and iodoacetamide treatment plate, 1(b): D,L-Hcy coating without iodoacetamide treatment plate, 2(a): LCys coating plate, 2(b): L-Hcy coating plate, 3(a): D-Hcy coating plate, 3(b) L-Hcy coating plate, and (C) identified epitope site for the antiHcy monoclonal antibody (- $\mathrm{CH}_{2} \mathrm{CH}_{2} \mathrm{SH}$, ethanethiol group).

including glutaraldehyde (G.A.). Other sulfur-containing amino acids (Cys and Met) were not detected by the antiHcy monoclonal antibody (Fig. 4A). The antigen epitope for the anti-Hcy monoclonal antibody was also investigated using indirect ELISA. The anti-Hcy monoclonal antibody could not react with the D,L-Hcy-coated ELISA plate after the iodoacetamide treatment because the thiol group of Hcy was blocked by the iodoacetamide reagent. In addition, the anti-Hcy monoclonal antibody could not recognize the Cys molecular structure $\left(-\mathrm{CH}_{2} \mathrm{SH}\right)$, suggesting that the antiHcy monoclonal antibody had specifically recognized the ethanethiol group $\left(-\mathrm{CH}_{2} \mathrm{CH}_{2} \mathrm{SH}\right)$ of Hcy (Fig. 4B). Indeed, the anti-Hcy monoclonal antibody could not distinguish D-Hcy from L-Hcy, suggesting that the amino group and carboxyl group of $\alpha$-carbon of Hcy were not involved in the

antigen epitope (Fig. 4C).

DTNB reagent was selected to examine the sensitivity of the anti-Hcy monoclonal antibody against Hcy. When Hcy and Cys were mixed with the DTNB reagent, the absorbance at $412 \mathrm{~nm}$ decreased due to the formation of TNB (Fig. 5A). On the other hand, when the Hcy and antiHcy monoclonal antibody were mixed in advance and the DTNB reagent was added later, the absorbance at $412 \mathrm{~nm}$ was lower than that of directly mixing DTNB with Hcy. Only the unblocked (remaining) -SH group of Hcy could react with the DTNB reagent because the anti-Hcy monoclonal antibody was bound to the ethanethiol group $\left(-\mathrm{CH}_{2} \mathrm{CH}_{2} \mathrm{SH}\right)$ of Hcy. That is, Hcy, which does not participate in the reaction with the anti-Hcy monoclonal antibody, can be detected by DTNB. In this way, the detectable concentration of Hcy was examined using a constant concentration of anti-Hcy monoclonal antibody with different Hcy concentrations. When the concentration of Hcy was $1 \mathrm{nM}$, most of the Hcy participated in the reaction with the anti-Hcy monoclonal antibody and was not detected by the DTNB reagent. These results suggest that the minimum concentration of detectable Hcy is $1 \mathrm{nM}$ (Fig. 5B).

The anti-Hcy monoclonal antibody sensitivity was also evaluated by monitoring a thiol-blocking reaction by iodoacetamide using competitive ELISA. In this experiment, iodoacetamide, a thiol-blocking reagent, was added at various concentrations on an ELISA plate coated with Hcy, Cys, Met, and homocysteinethiolactone (HTL) at constant concentrations, and the immunological signal changes between the anti-Hcy monoclonal antibody and four tested amino acids were then investigated. We found that as the concentration of the treated iodoacetamide increases, the blocked antigen will also increase but the anti-Hcy monoclonal antibody response decreases. As shown in Fig. $5 \mathrm{C}$, the binding ratio of the antigen to iodoacetamide is theoretically 1:1. Therefore, when $100 \mathrm{nM}$ of iodoacetamide was used, most of the antigens, Hcy, were blocked. At this time, approximately $1.8 \%$ of the signal was observed, indicating that the lowest concentration at which color development occurred was at $1 \mathrm{nM}$ of unblocked Hcy. In contrast, Cys, Met, and HTL did not change in response to the anti-Hcy monoclonal antibody after the iodoacetamide treatment at any concentration (Fig. 5D).

To examine the anti-Hcy monoclonal antibody specificity, the antibody binding ratio was measured using competitive ELISA. The ELISA plate surface was coated with Hcy (antigen) and an additional solution of Hcy, Cys, Met, and HTL was added to the plate to determine the decrease in 
A

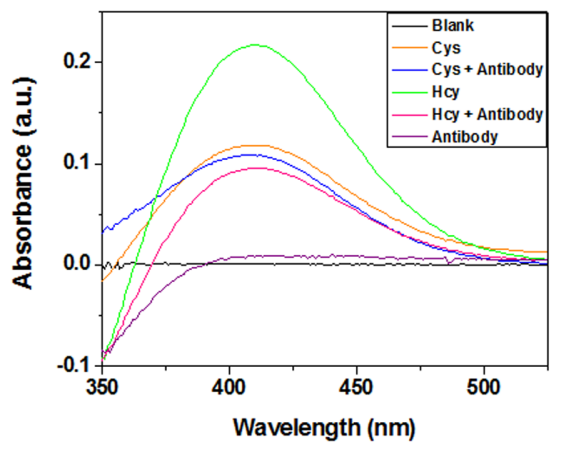

C

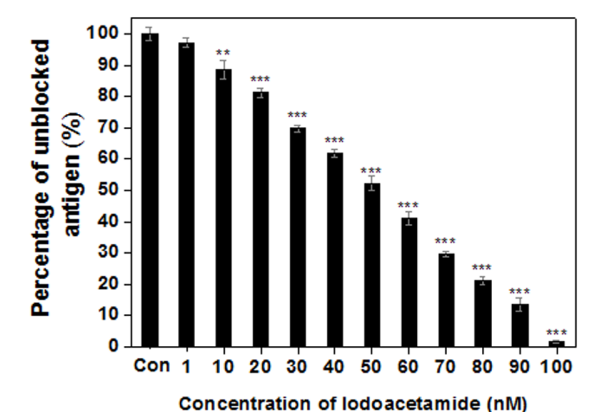

E

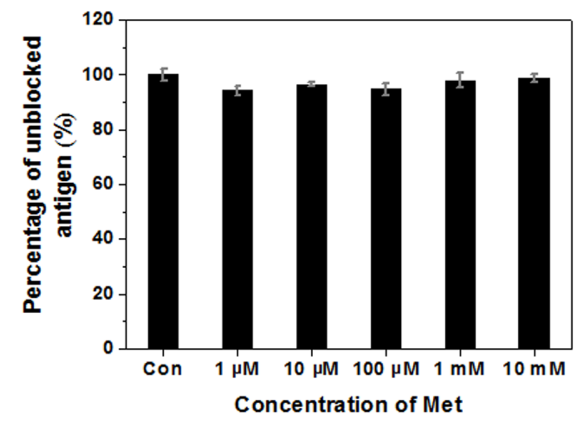

G

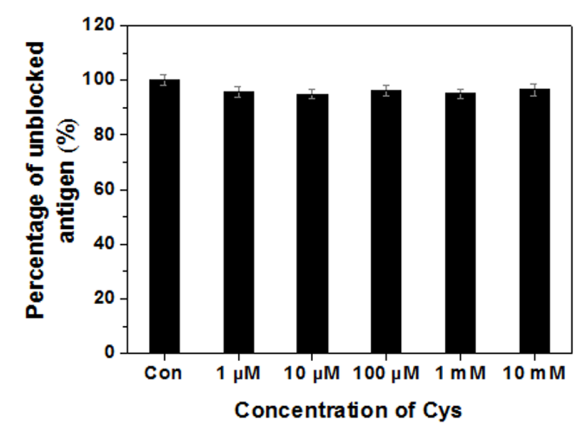

B

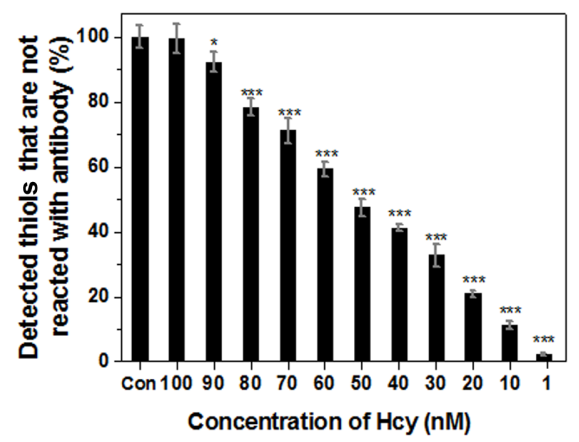

D

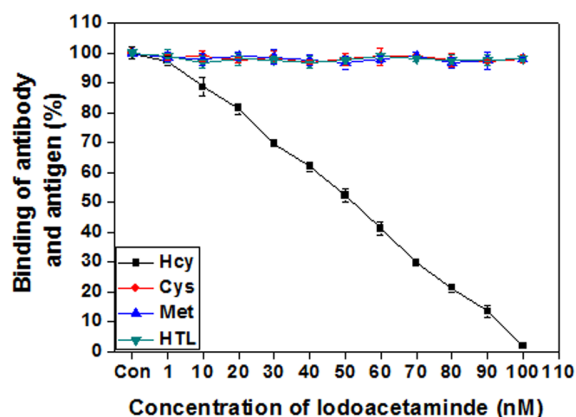

$\mathbf{F}$

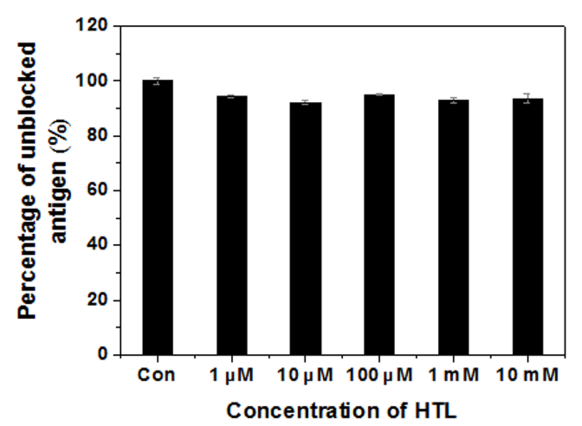

H

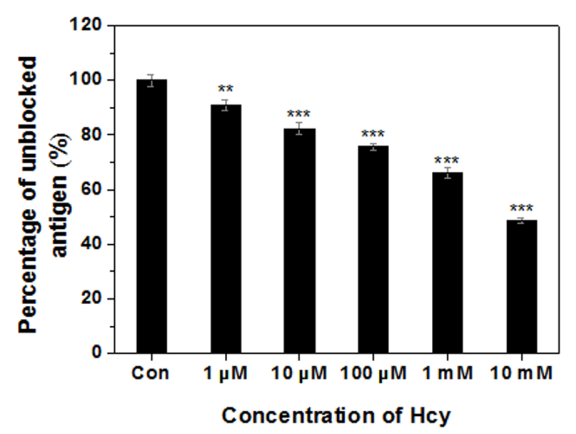

Fig. 5. Sensitivity and specificity of the anti-Hcy monoclonal antibody.

(A, B) Specificity of anti-Hcy monoclonal antibody against Hcy and sensitivity using a DTNB assay; (C, D) sensitivity of the anti-Hcy monoclonal antibody against Hcy and three other amino acids (Cys, Met, HTL) using competitive ELISA depending on the iodoacetamide concentration; (EH) the competitive ELISA experiment of the anti-Hcy monoclonal antibody against four free amino acids Met, HTL, Cys, and Hcy. Percentage (\%) of the y axis means the blocking ratio between before and after preincubation of Hcy with the anti-Hcy monoclonal antibody (Met: methionine, HTL: homocysteinethiolactone).

binding affinity between the coated antigen and anti-Hcy monoclonal antibody. The signal intensity of the ELISA will be decreased if the added free amino acids bind with the anti-Hcy monoclonal antibody. The results revealed a 

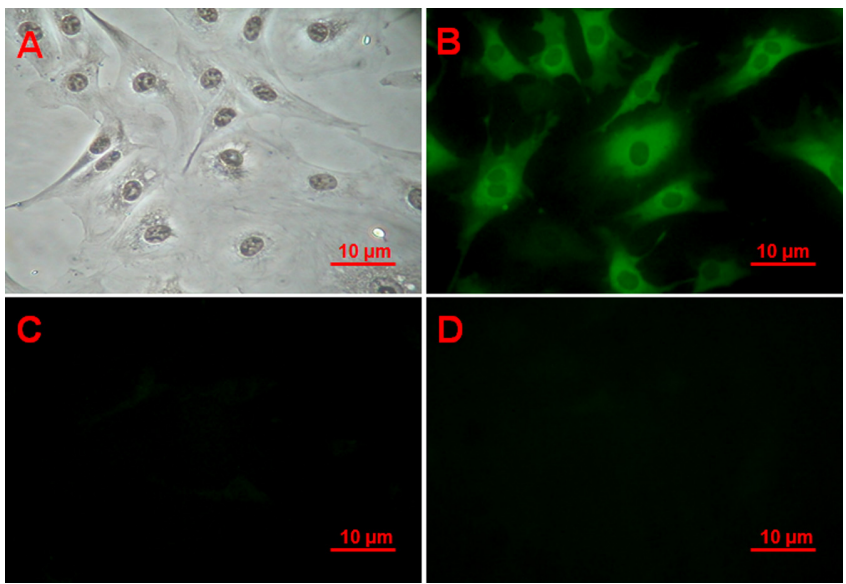

Fig. 6. Visualization of Hcy using the anti-Hcy monoclonal antibody in CPAE cells.

(A) Control; (B) CPAE cells treated with the anti-Hcy monoclonal antibody; (C) CPAE cells treated with iodoacetamide before the antiHcy monoclonal antibody treatment; (D) CPAE cells treated with preincubated anti-Hcy monoclonal antibody with Hcy.

decrease in signal only in the plate containing Hcy (Fig. 5H). Moreover, the antibody can recognize the liberated Hcy specifically but not Met (Fig. 5E), HTL (Fig. 5F), and Cys (Fig. 5G).

Hcy recognition in calf pulmonary artery endothelial (CPAE) cells was also visualized using the anti-Hcy monoclonal antibody. CPAE cells, which were combined with a fluorescein isothiocyanate (FITC)-tagged secondary antibody, were visualized as green signals compared to the control (Fig. 6A), suggesting that the anti-Hcy monoclonal antibody had effectively recognized Hcy in the CPAE cells (Fig. 6B). In addition, the iodoacetamide-treated CPAE cells did not show green signals by the blocked thiol groups of Hcy (Fig. 6C). Indeed, pre-incubated Hcy and anti-Hcy monoclonal antibody-treated CPAE cells were not detected as green signals because the anti-Hcy monoclonal antibody had already reacted with the Hcy molecules (Fig. 6D).

\section{Immunological Detection of Hcy by CB[7]}

The immunological detection efficacy of the Hcy-CB[7] complexes was examined using the anti-Hcy monoclonal antibody. The antigen-antibody reaction is known to be a reversible reaction and is available for host-guest binding studies [33]. The Hcy-coated 96-well plate reacted specifically with the anti-Hcy monoclonal antibody, and the signal absorbance at $405 \mathrm{~nm}$ was decreased by the secondary antirat $\mathrm{IgE}$ dilution (Fig. 7A). A 1,000 dilution (0.894 of absorbance at $405 \mathrm{~nm}$ ) was the appropriate dilution rate of secondary anti-rat IgE selected. The ELISA signal was suppressed by preincubation with $\mathrm{CB}[7]$ on the surface of the Hcy-coated 96-well plate (Fig. 7C). In addition, the signal suppression was proportional to the increase in $\mathrm{CB}[7]$ concentration due to the formation of a Hcy-CB[7] complex. The data suggest that $\mathrm{CB}[7]$ binds specifically and effectively to Hcy. The apparent $\mathrm{C}_{50 \%}$ value of $\mathrm{CB}[7]$ was calculated to be $87.7 \mathrm{nmol}$ (Fig. 7B). The interpretation of other experimental results is shown as a schematic model (Fig. 7D).

\section{Discussion}

Thus far, research on cucurbituril-based molecular recognition has been performed by ${ }^{1} \mathrm{H}$ nuclear magnetic resonance (NMR) spectroscopy, mass spectrometry (MS), isothermal titration calorimetry (ITC), and single-crystal crystallography. This is the first report concerning complexation formation of Hcy with CB[7] using three simple and novel methods.

The experimental data from the DTNB reagent, enzyme, and antibody strongly suggest that the thiol-containing ethylene side chain of Hcy is located inside of the CB[7] cavity under neutral aqueous conditions. On the other hand, the data also show that the ratio was only approximately $50 \%$ (Table 1). That is, the remaining $50 \%$ of the ethanethiol group of Hcy reacts with the DTNB reagent (Fig. 2E), hCGL enzyme (Fig. 3E), and antibody protein (Fig. 7B). A schematic model of host-guest complex formation of Hcy and Cys with CB[7] was proposed based on the data (Fig. 8).

In this model, half of the ethanethiol group of Hcy was buried in the cavity of $\mathrm{CB}$ [7] (Fig. 8A2). Moreover, half of the positively-charged ammonium group $\left(\mathrm{NH}_{3}{ }^{+}\right)$of Hcy was accommodated at the site of the carbonyl portal of $\mathrm{CB}[7]$ and the carboxylate group of Hcy was located

Table 1. Hcy-CB[7] binding ratio depend on CB[7] molar mass. (Hcy; 2 nmol).

\begin{tabular}{|c|c|c|c|c|c|c|c|}
\hline $\mathrm{CB}[7]$ (nmol) & 48 & 96 & 144 & 192 & 240 & 480 & $\mathrm{C}_{50 \%}(\mathrm{nmol})$ \\
\hline Chemical detection & $26.0 \pm 1.3 \%$ & $35.6 \pm 0.2 \%$ & $41.4 \pm 1.8 \%$ & $48.5 \pm 0.5 \%$ & $48.8 \pm 0.9 \%$ & $50.2 \pm 0.9 \%$ & $58.2 \pm 1.1$ \\
\hline Enzymatic detection & $17.4 \pm 1.5 \%$ & $28.6 \pm 0.5 \%$ & $33.7 \pm 0.9 \%$ & $38.9 \pm 1.1 \%$ & $41.7 \pm 1.7 \%$ & $46.1 \pm 0.7 \%$ & $97.7 \pm 1.0$ \\
\hline Immunological detection & $19.7 \pm 1.1 \%$ & $29.5 \pm 0.6 \%$ & $37.6 \pm 1.5 \%$ & $42.2 \pm 1.5 \%$ & $46.6 \pm 1.1 \%$ & $47.5 \pm 1.4 \%$ & $87.7 \pm 0.8$ \\
\hline
\end{tabular}



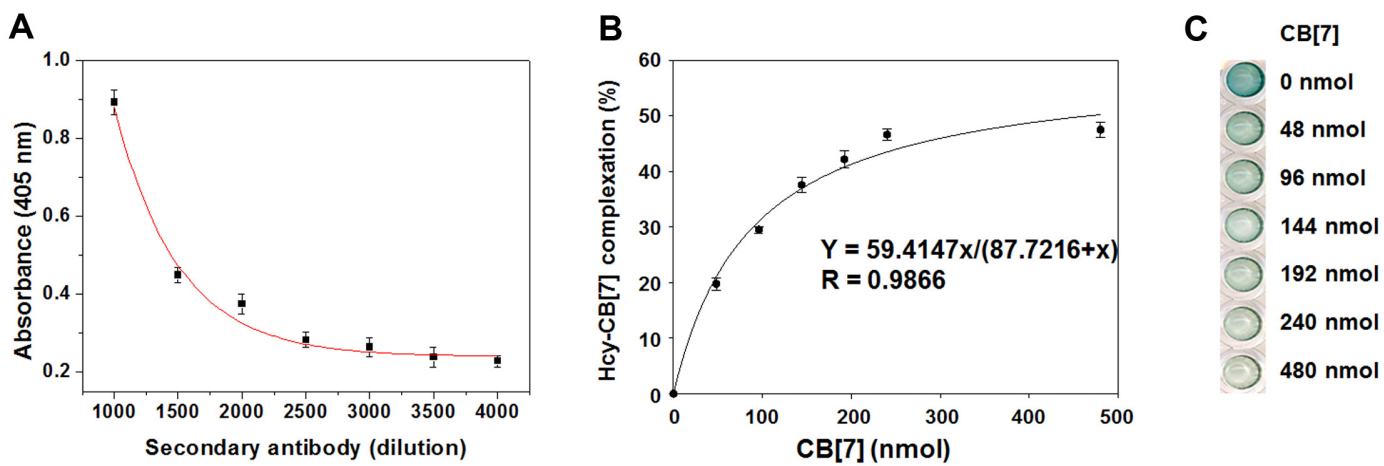

D

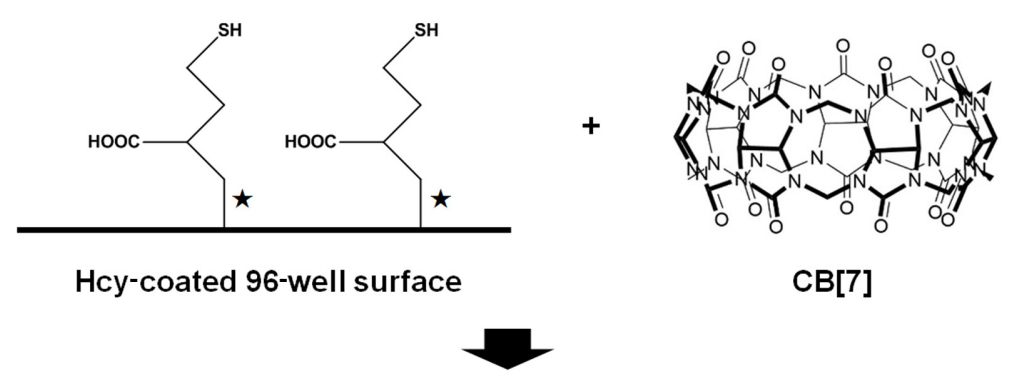

No signal

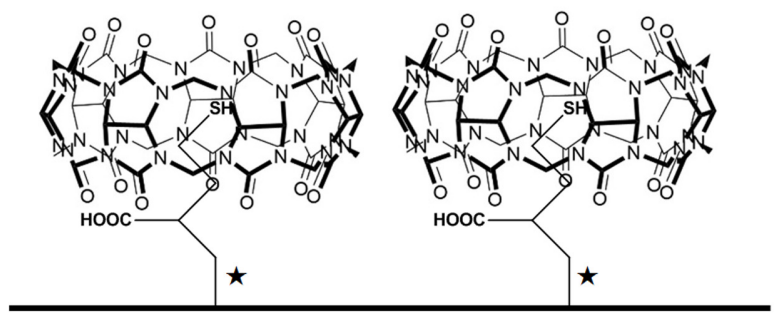

Hcy-CB[7] complex

Fig. 7. Immunological detection method for Hcy.

(A) Hcy-coated 96-well plate verification depends on the secondary monoclonal antibody dilution ratio; (B) calculated $\mathrm{C}_{50 \%}$ value for $\mathrm{CB}[7]$ from absorbance change by the equation, $\Delta \mathrm{A}=\Delta \mathrm{A}_{\max }\{\mathrm{CB}[7]\} / \mathrm{C}_{50 \%}+\{\mathrm{CB}[7]\} ;$ (C) ELISA raw data when $\mathrm{CB}[7]$ and Hcy are preincubated before the ELISA test; (D) a schematic image of Hcy-CB[7] complexation using indirect ELISA; $\star$ site represents the $-\mathrm{NH}-\left(\mathrm{CH}_{2}\right)_{5}-\mathrm{NH}-$ group, which was connected as a linker between the ELISA plate surface and Hcy.

outside of the CB[7] cavity, presumably due to electronic repulsion between the anionic charge of the carboxylate and the carbonyl oxygen atoms of the $\mathrm{CB}$ [7] ring (Fig. 8A1). On the other hand, Cys does not form complexes with $\mathrm{CB}$ [7] and exists in the free monomer form or the methylene thiol group must be exposed outside of $\mathrm{CB}$ [7] because the DTNB reagent and hCGL enzyme can fully recognize the methylene thiol group of Cys (Fig. 8B). In addition, the ammonium group might be positioned toward CB[7] [34]. The electrospray ionization mass spectrometry (ESI-MS) data also revealed the formation of 1:1 stoichiometric hostguest inclusion complexes for Hcy and $\mathrm{CB}[7]$, but no significant host-guest complexes signal between Cys and CB[7] (unpublished data). The ESI-MS data suggest that Cys does not form a stable complex with $\mathrm{CB}$ [7]; at least the equilibrium for complexation should be inclined toward a freer Cys (Fig. 8B).

In Table 1, the Hcy-CB[7] binding ratio showed an increasing tendency but differed slightly depending on the $\mathrm{CB}$ [7] molar ratio among the three methods. These results indicate the different stereospecific accessibility between the exposed ethanethiol group of Hcy and the reagent, hCGL protein, and antibody. In addition, the reaction turnover rate also might affect Hcy-CB[7] complexation. In 
A

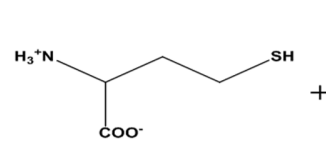

Hcy

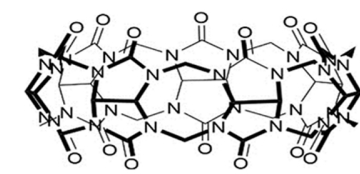

$\mathrm{CB}[7]$

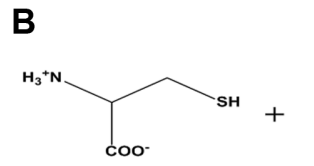

Cys

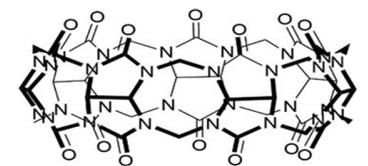

$\mathrm{CB}[7]$
(1)

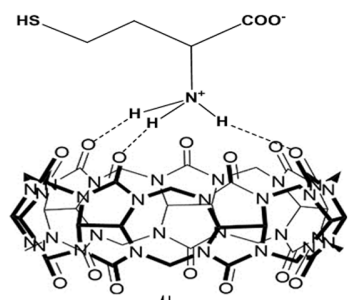

(2)
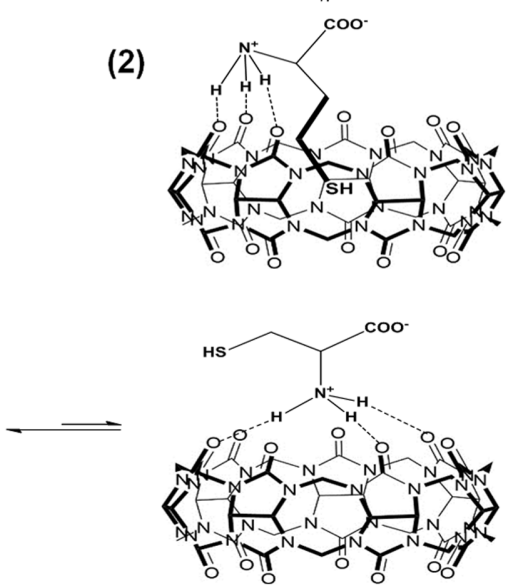

Fig. 8. Proposed schematic image of Hcy with $\mathrm{CB}[7]$ complexation.

$\mathrm{CB}[7]$ could combine with Hcy, which has relatively stronger hydrophobicity due to two methylene groups $\left(-\mathrm{CH}_{2} \mathrm{CH}_{2}-\right)$ and van der Waals forces in the CB[7] cavity and hydrogen bonding and ion-dipole interactions between the carbonyl oxygen atoms of CB[7] portal and hydrogen of Hcy amino group. On the other hand, the methylene thiol group of Cys, which has weaker hydrophobicity due to having only one methylene group $\left(-\mathrm{CH}_{2}-\right)$ compared to Hcy, does not enter the $\mathrm{CB}[7]$ cavity.

general, the equilibrium of the complexation always changes dynamically according to the ratio of the chemical species. The ethanethiol group-exposed Hcy-CB[7] complex (Fig. 8A1) can react with the DTNB reagent, enzyme, and antibody. As complexation proceeds, the ethanethiol group exposed Hcy-CB[7] complex (Fig. 8A1) species decreases and a new re-equilibrium is reached between the ethanethiol group-exposed Hcy-CB[7] complex (Fig. 8A1) and the ethanethiol group-shielded Hcy-CB[7] complex (Fig. 8A2). For example, when the molar ratio of $\mathrm{CB}[7]$ at the formation of Hcy-CB[7] complex is 480 , approximately $46.1 \%$ of the complex was detected by hCGL quantitation and $50.2 \%$ of the complex was detected by the DTNB reagent. The data may be affected by differences in the microscopic experimental conditions, such as temperature, $\mathrm{pH}$, and salt concentration in the buffer used. On the other hand, the data is due to the difference between the rate at which the enzyme degrades Hcy and the rate at which DTNB reacts with the thiol group. This is probably because the reaction took place before the re-equilibrium between ethanethiol group exposed Hcy-CB[7] complex (Fig. 8A1) and the ethanethiol group shielded-Hcy-CB[7] complex (Fig. 8A2) was completed. The low detection ratio by hCGL (46.1\%) suggests that the complexation of hCGL is faster than the reaction rate of DTNB with Hcy-CB[7] (Fig. 8A1). The apparent half complexation formation concentration $\left(\mathrm{C}_{50 \%}\right.$ value) of the three methods were between 58.2 and $97.7 \mathrm{nmol}$. This suggests that the affinity between the ethanethiol group-exposed Hcy-CB[7] complex (Fig. 8A1) and hCGL was lowest, even though hCGL complexation was fastest among the three methods. Because the concentration of total homocysteine in the plasma or serum is approximately 5 to $10 \mu \mathrm{M}$, the host-guest complexation will be useful in detecting the cardiovascular risk factor, Hcy. Overall, this paper proposed host-guest complexation by Cys and Hcy with CB[7] (Fig. 8). CB[7] could combine with Hcy, which has strong hydrophobicity because of its two methylene groups $\left(-\mathrm{CH}_{2} \mathrm{CH}_{2}-\right)$, and van der Waals forces in the CB[7] cavity. On the other hand, Cys, which has weak hydrophobicity due to having only one methylene 
group $\left(-\mathrm{CH}_{2}-\right)$ compared to Hcy, could not react with СB[7]. Therefore, the differing binding abilities of Hcy and Cys towards the $\mathrm{CB}[7]$ host should lead to the simple and useful detection/determination of Hcy in plasma or serum.

\section{Acknowledgment}

This work was supported by Kumoh National Institute of Technology.

\section{Conflict of Interest}

The authors have no financial conflicts of interest to declare.

\section{References}

1. Clarke R, Smith AD, Jobst KA, Refsum H, Sutton L, Ueland PM. 1998. Vitamin B12, and serum total homocysteine levels in confirmed Alzheimer disease. Arch. Neurol. 55: 1449-1455.

2. Nygård O, Vollset SE, Refsum H, Stensvold I, Tverdal A, nordrehaug JE, et al. 1995. Total plasma homocysteine and cardiovascular risk profile: the Hordaland homocysteine study. JAMA 274: 1526-1533.

3. Ueland PM, Refsum H, Beresford SA, Vollset SE. 2000. The controversy over homocysteine and cardiovascular risk. Am. J. Clin. Nutr. 72: 324-332.

4. Özkan Y, Özkan E, Şimşek B. 2002. Plasma total homocysteine and cysteine levels as cardiovascular risk factors in coronary heart disease. Int. J. Cardiol. 82: 269-277.

5. Finkelstein J. 1998. The metabolism of homocysteine: pathways and regulation. Eur. J. Pediatr. 157: S40-S44.

6. Selhub J, Miller JW. 1992. The pathogenesis of homocysteinemia: interruption of the coordinate regulation by S-adenosylmethionine of the remethylation and transsulfuration of homocysteine. Am. J. Clin. Nutr. 55: 131-138.

7. Cho H-N, Jhee K-H. 2014. Direct conversion of Lselenomethionine into methylselenol by human cystathionine $\gamma$-lyase. Microbiol. Biotechnol. Lett. 42: 11-17.

8. Blom HJ, Smulders Y. 2011. Overview of homocysteine and folate metabolism. With special references to cardiovascular disease and neural tube defect. J. Inherit. Metab. Dis. 34: 75-81.

9. Chen X, Jhee K-H, Kruger WD. 2004. Production of the neuromodulator $\mathrm{H}_{2} \mathrm{~S}$ by cystathionine $\beta$-synthase via the condensation of cysteine and homocysteine. J. Biol. Chem. 279: 52082-52086.

10. Yang G, Wu L, Jiang B, Yang W, Qi J, Cao K, et al. 2008. $\mathrm{H}_{2} \mathrm{~S}$ as a physiologic vasorelaxant: hypertension in mice with deletion of cystathionine $\gamma$-lyase. Science 322: 587-590.

11. Kim K-R, Byun H-J, Cho H-N, Kim J-H, Yang S-A, Jhee K-H. 2011. Overexpression and activity analysis of cystathionine $\gamma$-lyase responsible for the biogenesis of $\mathrm{H}_{2} \mathrm{~S}$ neurotransmitter.
J. Life Sci. 21: 119-126.

12. Inoue $T$, Kirchhorff JR. 2002. Determination of thiols by capillary electrophoresis with amperometric detection at a coenzyme pyrroloquinoline quinone modified electrode. Anal. Chem. 74: 1349-1354.

13. Wang W, Rusin O, Xu X, Kim KK, Escobedo JO, Fakayode SO, et al. 2005. Detection of homocysteine and cysteine. J. Am. Chem. Soc. 127: 15949-15958.

14. Rusin O, St. Luce NN, Agbaria RA, Escobedo JO, Jiang S, Warner IM, et al. 2004. Visual detection of cysteine and homocysteine. J. Am. Chem. Soc. 126: 438-439.

15. Wang J, Liu Y, Jiang M, Li Y, Xia L, Wu P. 2018. Aldehydefunctionalized metal-organic frameworks for selective sensing of homocysteine over Cys, GSH and other natural amino acids. Chem. Comm. 54: 1004-1007.

16. Niu L-Y, Chen Y-Z, Zheng H-R, Wu L-Z, Tung C-H, Yang Q-Z. 2015. Design strategies of fluorescent probes for selective detection among biothiols. Chem. Soc. Rev. 44: 6143-6160.

17. Fan W, Huang X, Shi X, Wang Z, Lu Z, Fan C, Bo Q. 2017. A simple fluorescent probe for sensing cysteine over homocysteine and glutathione based on PET. Spectrochim. Acta A Mol. Biomol. Spectrosc. 173: 918-923.

18. Wang W, Li L, Liu S, Ma C, Zhang S. 2008. Determination of physiological thiols by electrochemical detection with piazselenole and its application in rat breast cancer cells 4T-1. J. Am. Chem. Soc. 130: 10846-10847.

19. Li J, Loh XJ. 2008. Cyclodextrin-based supramolecular architectures: syntheses, structures, and applications for drug and gene delivery. Adv. Drug Deliv. Rev. 60: 1000-1017.

20. Busschaert N, Caltagirone C, Van Rossom W, Gale PA. 2015. Applications of supramolecular anion recognition. Chem. Rev. 115: 8038-8155.

21. Barrow SJ, Kasera S, Rowland MJ, del Barrio J, Scherman OA. 2015. Cucurbituril-based molecular recognition. Chem. Rev. 115: 12320-12406.

22. Biedermann F, Nau WM. 2014. Noncovalent chirality sensing ensembles for the detection and reaction monitoring of amino acids, peptides, proteins, and aromatic drugs. Angew. Chem. Int. Edit. 53: 5694-5699.

23. Gao Z-Z, Lin R-L, Bai D, Tao Z, Liu J-X, Xiao X. 2017. Hostguest complexation of cucurbit[8]uril with two enantiomers. Sci. Rep. 7: 44717.

24. Freeman W, Mock W, Shih N. 1981. Cucurbituril. J. Am. Chem. Soc. 103: 7367-7368.

25. Masson E, Ling X. Joseph R. Kyeremeh-Mensah L, Lu X. 2012. Cucurbituril chemistry: a tale of supramolecular success. Rsc Advances. 2: 1213-1247.

26. Urbach AR. Ramalingam V. 2011. Molecular recognition of amino acids, peptides, and proteins by cucurbit [n] uril receptors. Israel J. Chem. 51: 664-678.

27. Reisz JA, Bechtold E, King SB, Poole LB, Furdui CM. 2013. Thiol-blocking electrophiles interfere with labeling and detection of protein sulfenic acids. FEBS J. 280: 6150-6161. 
28. Sun Q, Collins R, Huang S, Holmberg-Schiavone L, Anand GS, Tan C-H, et al. 2009. Structural basis for the inhibition mechanism of human cystathionine $\gamma$-lyase, an enzyme responsible for the production of $\mathrm{H}_{2} \mathrm{~S}$. J. Biol. Chem. 284: 3076-3085.

29. Kishiro Y, Kagawa M, Naito I, Sado Y. 1995. A novel method of preparing rat-monoclonal antibody-producing hybridomas by using rat medial iliac lymph node cells. Cell Struct. Funct. 20: 151-156.

30. Ellman GL. 1959. Tissue sulfhydryl groups. Arch. Biochem. Biophy. 82: 70-77.

31. Okonjo KO, Fodeke AA. 2006. Reversible reaction of $5,5^{\prime}$ dithiobis (2-nitrobenzoate) with the hemoglobins of the domestic cat: acetylation of $\mathrm{NH}_{3}{ }^{+}$terminal group of the $\beta$ chain transforms the complex $\mathrm{pH}$ dependence of the forward apparent second order rate constant to a simple form. Biophy. Chem. 119: 196-204.

32. Jhee K-H, McPhie P, Miles EW. 2000. Domain architecture of the heme-independent yeast cystathionine $\beta$-synthase provides insights into mechanisms of catalysis and regulation. Biochem. 39: 10548-10556.

33. Karlsson R, Michaelsson A, Mattsson L. 1991. Kinetic analysis of monoclonal antibody-antigen interactions with a new biosensor based analytic system. J. Immunol. Methods 145: $229-240$

34. Thuéry P. 2011. L-cysteine as a chiral linker in lanthanidecucurbit [6] uril one-dimensional assemblies. Inorg. Chem. 50: 10558-10560. 